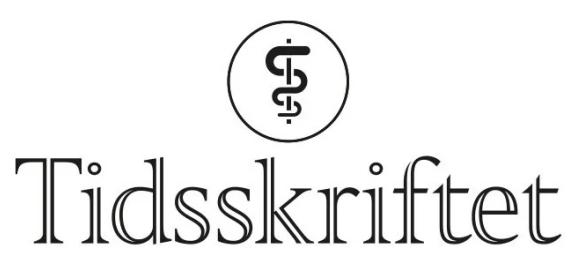

DEN NORSKE LEGEFORENING

\title{
Smittevern og hudutfordringer ved covid-19
}

DEBATT

\section{HILDE KRISTIN VINDENES}

Hilde Kristin Vindenes er spesialist i hud- og veneriske sykdommer, overlege ved Yrkesmedisinsk avdeling og Hudavdelingen, Haukeland universitetssjukehus, og stipendiat ved Klinisk institutt 2, Universitetet i Bergen.

Forfatteren har fylt ut ICMJE-skjemaet og oppgir ingen interessekonflikter.

\section{KRISTINE LILLEBØ}

Kristine Lillebø er spesialist i medisinsk mikrobiologi, overlege ved Nasjonal kompetansetjeneste for antibiotikabruk i spesialisthelsetjenesten og Mottaksklinikken, Haukeland universitetssjukehus. Forfatteren har fylt ut ICMJE-skjemaet og oppgir ingen interessekonflikter.

\section{TRUDE DUELIEN SKORGE}

Trude Duelien Skorge er ph.d., spesialist i arbeidsmedisin og bedriftslege ved Haukeland universitetssjukehus.

Forfatteren har fylt ut ICMJE-skjemaet og oppgir ingen interessekonflikter.

\section{KAJA IRGENS-HANSEN}

kaja.irgens-hansen@helse-bergen.no

Kaja Irgens-Hansen er ph.d., spesialist i arbeidsmedisin og overlege ved Yrkesmedisinsk avdeling, Haukeland universitetssjukehus.

Forfatteren har fylt ut ICMJE-skjemaet og oppgir ingen interessekonflikter.

\section{God etterlevelse av smittevernrutiner er viktig, men hyppig håndvask, bruk av desinfeksjonsmidler og langvarig bruk av personlig beskyttelsesutstyr kan være forbundet med risiko.}

Skjerpede rutiner som følge av covid-19-pandemien har skapt utfordringer i land med høyt press på helsevesenet. En studie fra Wuhan i Kina viste at $97 \%$ av helsepersonell rapporterte hudreaksjoner relatert til bruk av beskyttelsesutstyr. Hudreaksjonene inkluderte bl.a. erytem, skjelling, fissurer, erosjoner og sår. Vanligst var reaksjoner lokalisert til neserygg (83\%), kinn (79\%), hender (75\%) og panne (57\%). Helsepersonell som benyttet åndedrettsvern og øyebeskyttelse i mer enn seks timer eller utførte hyppig håndhygiene, hadde størst risiko for hudreaksjoner (1ㅣ). Hudreaksjoner og forverring av underliggende hudsykdom i tilknytning til bruk av beskyttelsesutstyr er kjent fra tidligere epidemier som 
ved sarsutbruddet i 2013 (므). Eksemutvikling ved bruk av beskyttelsesutstyr vil oftest være irritativt betinget. En studie fra sarsepidemien viste imidlertid at eksemutvikling knyttet til bruk av åndedrettsvern også kan være allergisk betinget (3). Vått arbeid er en av de sterkeste kjente prediktorene for utvikling av håndeksem. Definisjonen av vått arbeid er å ha våte hender $i \geq 2$ timer, vaske hendene $\geq 20$ ganger eller benytte hansker $i \geq 2$ timer per arbeidsdag. Selv eksponering for vått arbeid på $\leq 30$ minutter kan gi økt risiko for håndeksem (4).

En skadet hudbarriere vil være inngangsport for patogene mikrober. En tysk studie viste at sykepleiere med yrkesrelaterte hudsykdommer har 2-3 ganger høyere forekomst av kolonisering med meticillinresistente Staphylococcus aureus (MRSA) enn helsearbeidere generelt (5). Den økte forekomsten av kolonisering vurderes å skyldes svekket hudbarriere i kombinasjon med dårlig etterlevelse av håndhygiene. MRSA-smitte i helsevesenet er heldigvis mindre utbredt i Norge (므), men problemstillingen er allikevel ikke ukjent. Smitteoverføring av patogene mikrober vil kunne komplisere pasientforløpet for covid-19smittede. En utfordring for helsepersonell og samfunnet som helhet er at hudreaksjoner vil kunne være begrensende for arbeidsutførelse og medføre sykefravær (7.).

\section{Hvilke tiltak kan iverksettes?}

Hudreaksjoner etter bruk av beskyttelsesutstyr blant helsepersonell skyldes ofte hanskebruk (7.), men er under pandemien også sett etter bruk av annet beskyttelsesutstyr. Kunnskap knyttet til hudreaksjoner etter slik bruk er begrenset og baserer seg primært på erfaring fra pasientbehandling. Reaksjonene er oftest forbigående og går tilbake uten behandling dersom eksponeringen opphører eller blir redusert ( $\underline{8})$.

\section{«Hudreaksjoner vil kunne øke risikoen for smitte med patogene mikrober, gi nedsatt arbeidsevne og sykefravcr»}

Det er i enkelte land utviklet egne retningslinjer for håndtering av hudreaksjoner som følge av bruk av beskyttelsesutstyr (9.). I Norge finnes ingen nasjonale retningslinjer, men lokale anbefalinger er etablert. Åndedrettsvern må ha riktig størrelse og sitte godt for å unngå lekkasje. Stramtsittende beskyttelsesutstyr vil ikke forbedre beskyttelsen, men kan påvirke huden negativt (9.). Sår og erosjoner i ansiktet øker sannsynlighet for berøring og risiko for smitte (ㅁ). Barrierefilm kan benyttes forebyggende under beskyttelsesutstyret. Ved tilløp til trykkskader kan beskyttende plater tas i bruk, forutsatt at effekten av beskyttelsesutstyret ikke forringes (kan undersøkes med tetthetstest). For å redusere trykkbelastning anbefales det å veksle mellom ulike typer beskyttelsesutstyr. Rotasjon mellom arbeidsoppgaver vil kunne redusere den totale belastningen (9.). Ved mistanke om allergisk årsak til eksem bør den ansatte forsøke annet beskyttelsesutstyr og utredes for allergier. Ved intensivert håndhygiene anbefales $ø$ kt fokus på forebygging av hudreaksjoner og behandling av håndeksem.

Under en pandemi er håndhygieneprosedyrer og bruk av personlig beskyttelsesutstyr helt essensielt, men det er avgjørende at prosedyrer utføres riktig og at utstyret brukes rett. Hudreaksjoner vil kunne øke risikoen for smitte med patogene mikrober, gi nedsatt arbeidsevne og sykefravær. Det er viktig at helsepersonell kjenner til hvilke forebyggende tiltak som kan iverksettes og hva som kan være aktuell behandling dersom hudreaksjoner oppstår. 
1. Lan J, Song Z, Miao X et al. Skin damage among health care workers managing coronavirus disease2019. J Am Acad Dermatol 2020; 82: 1215-6. [PubMed][CrossRef]

2. Foo CC, Goon AT, Leow YH et al. Adverse skin reactions to personal protective equipment against severe acute respiratory syndrome-a descriptive study in Singapore. Contact Dermat 2006; 55: 291-4. [PubMed][CrossRef]

3. Donovan J, Kudla I, Holness LD et al. Skin reactions following use of n95 facial masks. Dermatitis 2007; 18: 104. [CrossRef]

4. Lund T, Petersen SB, Flachs EM et al. Risk of work-related hand eczema in relation to wet work exposure. Scand J Work Environ Health 2020; 46:3876. [PubMed][CrossRef]

5. Brans R, Kolomanski K, Mentzel F et al. Colonisation with methicillin-resistant Staphylococcus aureus and associated factors among nurses with occupational skin diseases. Occup Environ Med 2016; 73: 670-5. [PubMed][CrossRef]

6. Jørgensen SB, Handal N, Fjeldsæter KL et al. MRSA-forekomst blant helsepersonell ved smitteoppsporing i sykehus. Tidsskr Nor Legeforen 2018; 138. doi:10.4045/tidsskr.17.0364. [PubMed] [CrossRef]

7. Higgins CL, Palmer AM, Cahill JL et al. Occupational skin disease among Australian healthcare workers: a retrospective analysis from an occupational dermatology clinic, 1993-2014. Contact Dermat 2016; 75: 213-22. [PubMed][CrossRef]

8. Kantor J. Behavioral considerations and impact on personal protective equipment use: Early lessons from the coronavirus (COVID-19) pandemic. J Am Acad Dermatol 2020; 82:1087-8. [PubMed] [CrossRef]

9. Wounds UK. NHS guidance on helping to prevent facial skin damage beneath personal protective equipment. https://www.wounds-uk.com/news/details/nhs-guidance-on-helping-prevent-facial-skindamage-beneath-personal-protective-equipment Lest 7.5.2020.

Publisert: 8. mai 2020. Tidsskr Nor Legeforen. DOI: 10.4045/tidsskr.20.0365

Mottatt 22.4.2020, første revisjon innsendt 7.5.2020, godkjent 7.5.2020.

(C) Tidsskrift for Den norske legeforening 2023. Lastet ned fra tidsskriftet.no 26. april 2023. 